\title{
Sensory analysis of hydrolysed meat preparations
}

\author{
Análise sensorial de preparações com hidrolisados de carne
}

\author{
Maria Elisabeth Machado PINTO E SILVA ${ }^{1 *}$, Maria Carolina von ATZINGEN ${ }^{1}$
}

\begin{abstract}
The use of hydrolysed meat in diets contributes to the improvement of protein, vitamin and mineral supply. This work aims at checking the acceptance pattern in meat hydrolysates. Four preparations have been developed with three types of hydrolysates in domestic-like conditions. Acceptance was verified by means of sensory analysis using the nine-point hedonic scale. Sensory tests have been carried out in three sessions (according to the kind of hydrolysates). In the evaluation file, information on age groups has been included. The statistical analysis has been made by ANOVA and Tukey test. The best accepted preparation have been the turkey and chicken hydrolysed balls. Hydrolysates can be used in many different kinds of preparations, but it is necessary to know both the age group it will be used to and its sensory and chemicalphysical features to ensure the taste and the original appearance of the final product.
\end{abstract}

Keywords: sensory analysis; meat hydrolysates; acceptance test.

\section{Resumo}

A utilização de hidrolisados de carne em dietas melhora seu conteúdo protéico, de vitaminas e minerais. O objetivo do presente trabalho foi avaliar a aceitação de hidrolisados de carne. Quatro preparações foram desenvolvidas com três tipos de hidrolisados em condições similares às domésticas. . A aceitação foi avaliada com uso de escala hedônica de 9 pontos. Os testes foram realizados em três sessões (de acordo com o tipo de hidrolisado) e, incluiu-se na ficha de avaliação informações de idade. A análise estatística foi realizada por ANOVA e teste de Tukey. As preparações mais aceitas foram os bolinhos com hidrolisados de peru e frango. Os hidrolisados podem ser utilizados em diversas preparações, sendo necessário o conhecimento da faixa etária a qual se destinam, suas características sensoriais e físico-químicas, para garantir o sabor e a aparência do produto final.

Palavras-chave: análise sensorial; hidrolisados de carne; teste de aceitação.

\section{Introduction}

Synthetic formulas with protein hydrolysates and free amino acids were used in the nutritional treatment of individuals with limitation to digest intact protein (CHIANG; SHIH; CHU, 1999) in cases such as decreased luminal hydrolysis, gastric or liver failure (CLEMENTE, 2000), malnutrition associated with cancer, burns and traumas, bad absorption, metabolic disorders, and food allergies (ZARRABIAN et al., 1999; NEVES; MIRA; MARQUEZ, 2004).

Frokjaer (1994), presented the use of protein hydrolysates in elderly people's diet who do not usually consume enough protein to supply them with their basic needs due to loss of appetite, lonely meals, illnesses, or even lack of help to eat. Another use is in athletes' diets, in the shape of replenishing or maintenance drinks or for individuals who are controlling weight through balanced preparations.

Stabile et al., (1990) analysed the conditions for best efficiency of meat (beef, chicken, and fish) hydrolysates at low costs using fresh pineapple juice and obtained favourable results for its use in diets. This study shows that there are resources to guide the preparation of special diets for clinical use as well.
Several hospital catering services develop simple preparations, of everyday use, using domestic facilities to make it easier and guarantee that the patients who are discharged from the hospital can follow the diet, maintain it, and recover their nutritional condition.

Nutritional domiciliary support has been increasing in the last ten years, being considered an important part of the treatment (BOTT et al., 2001), because balanced diets with good palatability are a valuable tool when patients have to follow a dietary prescription.

The preparation of these diets is not always the result of just a simple adaptation. It is necessary to know what interactions may occur between different foods and how to avoid or mask those interactions so that acceptability can be improved. Pinto et al. (1998), developed preparations with hydrolysates under ordinary household conditions and verified good acceptance levels.

This work aims to evaluate the acceptance of meat (beef, turkey, and chicken) hydrolysates in preparations which are commonly used and in enteral nutrition used as oral supplement.

${ }^{1}$ Departamento de Nutrição, Faculdade de Saúde Pública, Universidade de São Paulo - USP, CEP 01246904, São Paulo - SP, Brasil, E-mail: mmachado@usp.br

${ }^{*}$ A quem a correspondência deve ser enviada 


\section{Materials and methods}

\subsection{Materials}

\section{Meat and proteolytic enzymes}

Six lots of the three different types of meat, beef (topside), turkey (breast), and chicken (breast) were used for preparing hydrolysates and for the recipes themselves. Juice from fresh ripe pineapples (Ananas comosus L.) from Hawaiian and Perola varieties was used as a source of bromelain, proteolytic enzyme.

\section{Equipment}

Domestic kitchenware was used to check the reproducibility of the orientation at clinical level.

\section{Selected recipes}

The selected preparations were: soup (beetroot and carrots), potato balls (potatoes, flour, spices), smoothies (orange and avocado) and grape mousse (grape juice, jelly) since these are common preparations in our diet and are easy to manipulate. Protein hydrolysates substituting the liquid were used in the preparations as follows: $150 \mathrm{~g}$ for the soup, $100 \mathrm{~g}$ for the potato balls, $25 \mathrm{~g}$ for the smoothies, and $100 \mathrm{~g}$ for the grape mousse. The recipes were selected from cooking books and leaflets distributed to the public by industries. A handmade enteral preparation from Instituto da Criança - HCFMUSP, Children's Institute - HCFMUSP, (carrots, potatoes, egg yolks, soybean extract, and chicken broth) was used as a reference. The chicken broth of the preparation was substituted for meat protein hydrolysates (beef, chicken, and turkey).

The ingredients were bought at local markets in São Paulo taking into account their characteristics of freshness and integrity.

\subsection{Methods}

Meat hydrolyzation was carried out according to the methodology described by Pinto et al. (1999). Meat and juice in equal proportions ( $1 \mathrm{~kg}$ of meat $/ 1 \mathrm{~kg}$ of juice) were homogenized, taken to double-boiling $\left(60^{\circ} \mathrm{C}\right)$ for 30 minutes, placed on direct heat until boiling for 5 minutes, and then sieved. The hydrolysates were prepared by a trained staff in the laboratory of Técnica Dietética, Faculdade de Saúde Pública (Dietetic Techniques Laboratory, College of Public Health USP) in domestic-like conditions.

\section{Preparation}

The original recipes were followed to establish the features of the product: colour, taste, and appearance. As a standard procedure, the liquid was replaced with the hydrolysate, and at the end of each test there were group discussions to come to a final preparation: similarity to the original pattern and necessary changes. The approved ones were presented for sensorial analysis.

\subsection{Sensory methods}

For the acceptance test of the preparations, the affective method in the verbally structured 9-point hedonic scale (from 9 - extremely like, 5 - neither like nor dislike, to 1 - extremely dislike) was used. In the evaluation file, there was information about age and remarks on the preparation concerning which aspects were the most or the least liked.

The four preparations were presented to a panel of non-professional tasters for evaluation together with a glass of water and the evaluation file; therefore, 3 sessions were necessary for each of the hydrolysates (beef, chicken, and turkey).

For the analysis of enteral formulas another session was carried out. The panellists received three samples of preparations (made of hydrolysed beef, chicken, and turkey) presented as creamy soup in disposable cups $(50 \mathrm{ml})$ together with a sensory file and a glass of water.

The sensory evaluation counted on a panel of individuals of both sexes, workers, teachers, and students from Faculdade de Saúde Pública - USP (College of Public Health - USP). 40 tasters took part in the sessions, an adequate number for this type of test according to Meilgaard, Civille and Carr, 1999. The tests were carried out in individual booths, especially designed for sensorial analysis in the Laboratório de Técnica Dietética, Departamento de Nutrição da Faculdade de Saúde Pública (Dietetic Techniques Laboratory, College of Public Health - USP).

For the experiment analysis, a statistics profile was used by means of variance (ANOVA) and Tukey test (FIZZ program for sensory analysis / Biosystem). The level of confidence adopted was that of $95 \%$. For the acceptance analysis according to age, the non-parametric test (Kruskal-Wallis) was used.

The preparation was considered as accepted when the majority of the tasters $(\geq 50 \%)$ showed results as, at least, "like slightly" (value 6) in the presented scale.

The project was approved by the Ethics Committee of the Faculdade de Saúde Pública - USP (College of Public Health USP).

\section{Results and discussion}

\subsection{Preparations}

The preparations were the same for the three types of meat (beef, turkey, and chicken), hydrolysates, and each session took place with just one kind of meat. The sequence of types of meat for tasting was chosen at random: turkey, beef, and chicken.

Table 1 shows the average obtained by statistical analysis, based on the value attributed in the hedonic scale by tasters. Although the beet soup with beef hydrolysate showed the highest average, it is not statistically different from the soup with other hydrolysates, which were classified by tasters as quite near to "like slightly". The results lead to the conclusion that the type of hydrolysates has little influenced this preparation (Figure 1). 
Table 1. Means and standard-deviation and acceptance of the preparations with the three types of hydrolysates.

\begin{tabular}{|c|c|c|c|c|c|c|}
\hline \multirow[t]{2}{*}{ Preparation } & \multicolumn{2}{|c|}{ Beef hydrolysate } & \multicolumn{2}{|c|}{ Chicken hydrolysate } & \multicolumn{2}{|c|}{ Turkey hydrolysate } \\
\hline & Mean \pm SD & \%acceptance & Mean \pm SD & \%acceptance & Mean \pm SD & \%acceptance \\
\hline Potato balls & $7.49^{\mathrm{a}} \pm 1.10$ & 54 & $7.63^{\mathrm{b}} \pm 1.04$ & 96 & $7.78^{\mathrm{b}} \pm 0.96$ & 81 \\
\hline Vegetable and fruit smoothies & $5.66^{\mathrm{a}} \pm 1.56$ & 66 & $6.44^{\mathrm{a}} \pm 1.58$ & 67 & $6.56^{\mathrm{a}} \pm 1.83$ & 62 \\
\hline Mousse & $7.24^{\mathrm{a}} \pm 1.26$ & 66 & $7.66^{\mathrm{a}} \pm 1.13$ & 83 & $7.68^{a} \pm 0.93$ & 85 \\
\hline Beet soup & $6.49^{\mathrm{a}} \pm 1.50$ & 76 & $6.56^{\mathrm{a}} \pm 1.29$ & 62 & $6.63^{\mathrm{a}} \pm 1.34$ & 68 \\
\hline Enteral formula & $5,28^{\mathrm{ab}} \pm 2,11$ & 53 & $5,75^{\mathrm{b}} \pm 1,85$ & 63 & $4,85^{a} \pm 2,33$ & 48 \\
\hline Media & & 63 & & 72 & & 71 \\
\hline
\end{tabular}

${ }^{a, b}$ Equal letters by line do not differ statistically $(\mathrm{p} \leq 0.05)$.

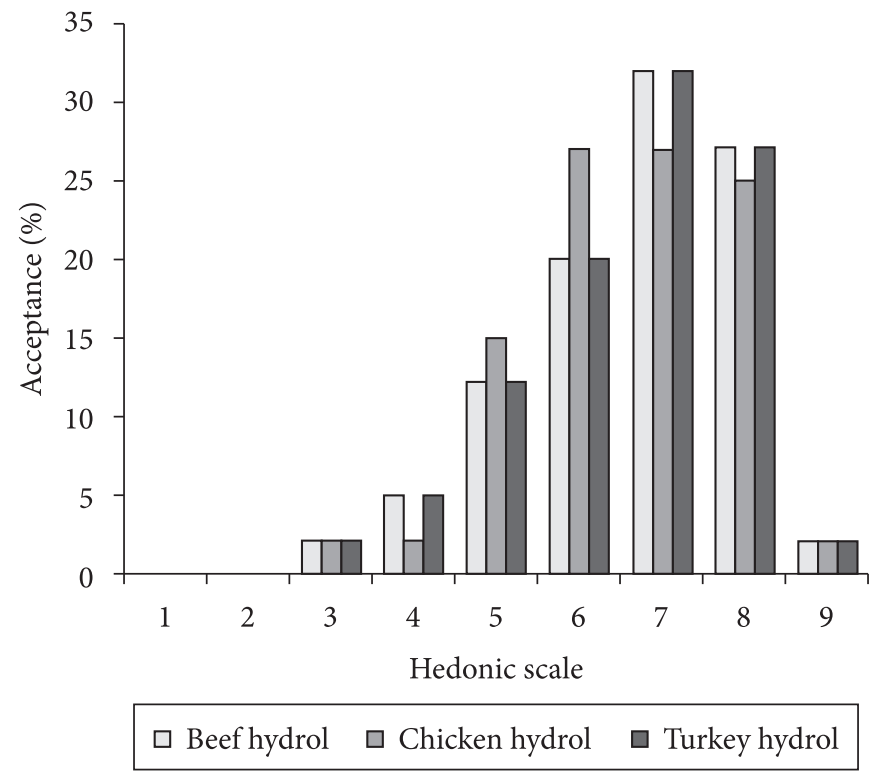

Figure 1. Acceptance of soup with hydrolysate.

The tasters' remarks about the hydrolysed beef soup concerning colour, consistence, taste, and pleasant seasoning (20\%). Nevertheless, references to a slightly bitter aftertaste (7.5\%), non-defined colour (2\%), and liver taste (5\%) were considered rejection factors despite the verified low percentage.

With regard to the hydrolysed chicken soup, the remarks were similar to those made about the beef hydrolysates: consistence, taste, and pleasant seasoning (25\%), and slightly bitter aftertaste (5\%); however, there was no remark about the liver taste by the group involved, as it occurred with the separate hydrolysate.

The texture, colour, taste, and seasoning of the soup with turkey hydrolysates were pointed out as being pleasant and typical of the preparation by $30 \%$ of the tasters; and concerning the feature "like least", $3 \%$ mentioned a non-defined aftertaste. As for the aftertaste, which could not be identified, they observed it as a non-desirable bitter taste.

The results for the potato ball preparation did not show a significant statistical difference from the turkey and chicken hydrolysates, but the beef hydrolysates presented difference. In the hedonic scale (Figure 2), the balls made of turkey and

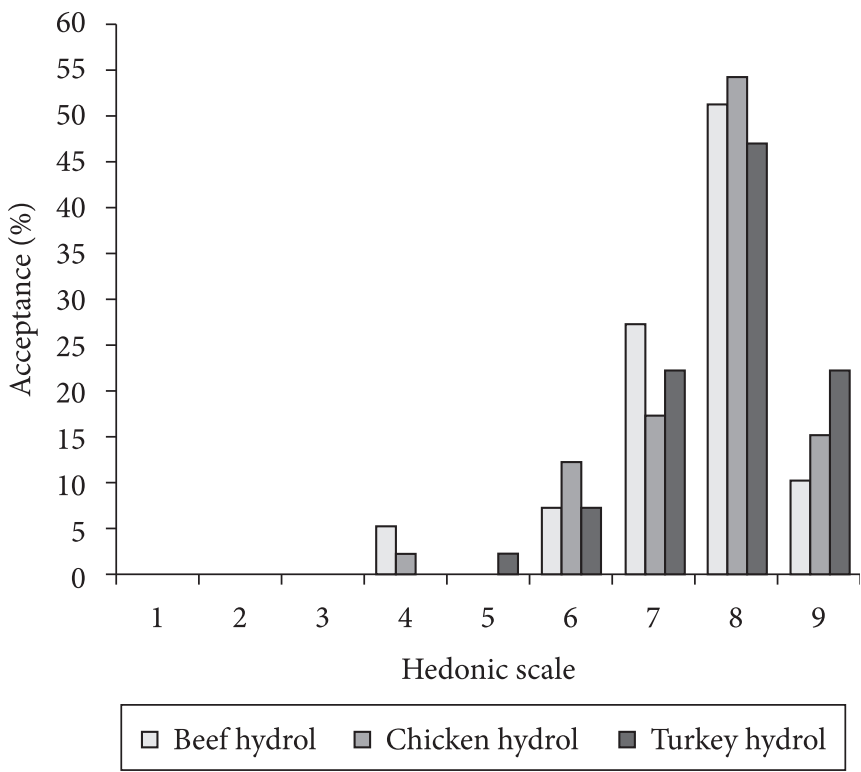

Figure 2. Acceptance of potato balls with hydrolysate.

chicken hydrolysates were classified as somewhere near "like very much" and the beef as "like moderately". The turkey and chicken hydrolysates showed the best results concerning this kind of preparation, but a direct difference from the beef could not be established since the high fat content that remained in the balls was the only one referred to as an undesirable aftertaste.

The tasters' remarks concerning the texture, smell, and appearance of the balls with beef hydrolysate were very satisfactory (17\%), as well as those of the chicken concerning texture, appearance, and crunchiness (20\%) while for the turkey, it was (25\%). The "dislike" ranking group concerned the excessive amount of fat $(9 \%)$ due to the fact they were fried - for the beef and turkey (3\%), and (5\%) for chicken since it was very tender inside. The observations concerning fat can be solved if the balls are prepared in the oven.

The smoothies did not show statistically meaningful differences, being the average of those prepared with turkey and chicken hydrolysates a little higher, which, in the hedonic scale, it means something next to "like slightly" and "neither like nor dislike" for the beef hydrolysates (Figure 3). By observing the differences obtained on the averages, one can notice that the preparations were not very much affected by the hydrolysates. 


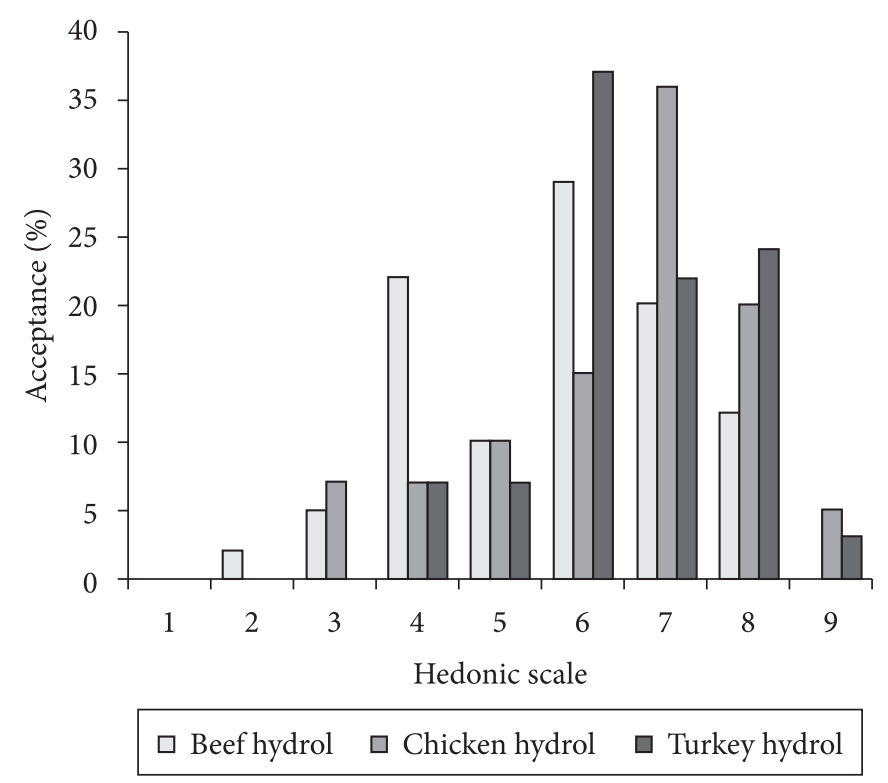

Figure 3. Acceptance of vegetable and fruit smoothies with hydrolysate.

The smoothies with hydrolysates were accepted by their colour, taste, and consistence; the results obtained were $18 \%$ for the one with beef hydrolysate, $20 \%$ for the chicken hydrolysate and for the turkey hydrolysate. Concerning the taste of the mixture of fruit and vegetables and the presence of sediments, the results were $12 \%$ for the beef hydrolysate and $10 \%$ for the chicken. There was rejection of the preparation by some tasters (5\%) due to excess of sediments (10\%) for the beef and turkey hydrolysate and $8 \%$ for the chicken hydrolysate. The rejection percentage concerning the slightly unpleasant sour taste was $5 \%$ for the beef and chicken hydrolysate and $7 \%$ for the turkey hydrolysate, and concerning that they were very sweet $(5 \%)$ or with an undesirable bitter aftertaste it was $5 \%$ for the beef hydrolysate, $2 \%$ for the chicken hydrolysate, and $3 \%$ for the turkey hydrolysate.

However, concerning the sediment which is typical of this preparation, one can, by increasing the blending time, improve this aspect making it creamier, less granulated, or adding other fruit or vegetables to eliminate or minimize acidity.

Statistically different averages between the mousse and the three hydrolysates have not been observed, but the turkey hydrolysate was a little higher. Nevertheless, the three, according to the hedonic scale, are near the scale "like slightly" (Figure 4). One can notice, however, that the mousse with turkey hydrolysate presented a slightly higher result than the ones with the other two types of hydrolysates, which did not mean, however, a difference in the use of any of the three hydrolysates in the mousse.

The tasters' remarks concerning the mousse with hydrolysed beef were classified as "like it best" in the evaluation file, and there were 17 and $15 \%$ positive remarks for the turkey hydrolysate in terms of texture, colour, and taste. They were classifies as "like it least" in terms of the sweet flavour and consistency of the beef hydrolysate $(2,5 \%)$ and $5 \%$ for the turkey hydrolysate. The negative aspects pointed out were the final acidity (5\%) and egg taste $(2,5 \%)$ for mousses with beef hydrolysate.

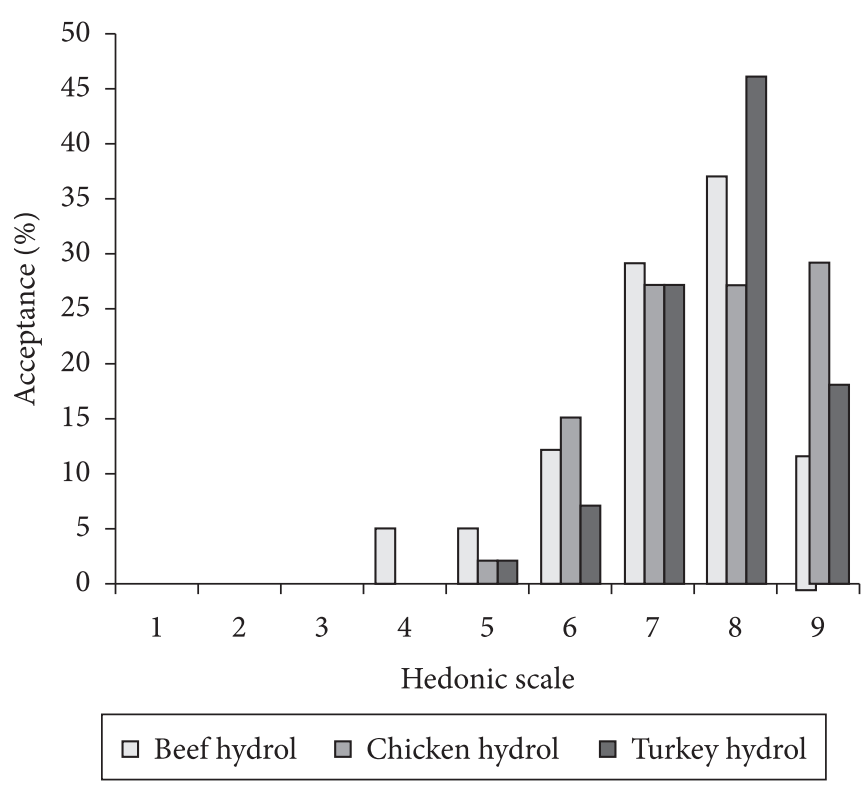

Figure 4. Acceptance of musse with hydrolysate.

In all analyses, one can observe that the mean value higher than 7 was obtained by the potato balls with turkey and chicken hydrolysates and by the mousse with turkey hydrolysates. In fact, these were the best-accepted preparations as the evaluation files show. One could notice an unexpected iron taste in the preparations with the beef hydrolysates, which did not occur in the chicken and turkey hydrolysates. Those were very little affected in taste and colour.

It was observed that the preparations with chicken hydrolysates were not rejected. As for the other hydrolysates some small changes can improve their acceptance. Taking into consideration the distribution presented, the remarks in the evaluation file, and the small percentages related to the rejection aspects one can say that the preparations with the three kinds of meat had satisfactory acceptance according to the hedonic scale.

The variety of responses was evaluated taking into account tasters' age in connection with the specific features of the preparations through the rankings of "most" and "least liked" in the evaluation files according to the three age groups: under 20 , from 20 to 40 , and over 40 years old.

From the rankings "I liked the soup best", the salty flavour was mentioned by the under 20 year old age group; and seasoning, by the group of over 40. As for "the least liked", the salty taste appears in both age groups over 20 , which showed the preference for the salty taste in the group aged under 20 and the seasoning for individuals above this age.

As for soup, concerning the degree of like or dislike, in the age group over $40,49 \%$ of the rankings were marked above "like slightly", whereas in the group under 20 it was 45 and $40 \%$ for the group from 20 to 40 . There was a statistically meaningful difference for the three kinds of soup concerning age groups, individuals over $40(p<0.05)$ demonstrated better acceptance for the soup. According to the marketing companies the acquisition of soups is greater within older people (over 40 years old) than younger. 
With regard to the balls, the good acceptance did not depend on the individual's age group.

As for the smoothies, in the group age from 20 to 40, the rankings "I liked best" were about the presence of the sediment, which was also mentioned by a smaller number of individuals as the least liked (5\%) factor. In the other two age groups, the sediment was considered undesirable. The largest number of points above 7 was observed in the age group over 40 (60\%); from 20 to 40, only 40\% ranked this much. For the smoothies with turkey hydrolysates, there was a statistical difference. There was better acceptance in the age group over $40(\mathrm{p}<0.05)$. For the scale above 5 ("neither like nor dislike"), the results were $78 \%$ for the group under $20,67 \%$ for 20 to 40 , and $80 \%$ for the group over 40 . Thus, these data show that the smoothies have more varied acceptance among people under 40 and better acceptance among people above this age.

With regard to the mousse, the remarks in the evaluation file were uniform throughout the different age groups concerning "I liked best", but the tasters under 40 ranked "Iliked least" the strong flavour. In the distribution of points above $7,88 \%$ were from people under $20 ; 71 \%$ from 20 to 40 , and $83 \%$ from people over 40 . Scale under 5 was observed only in $10 \%$ of the individuals from 20 to 40 and in $17 \%$ for those over 40 . Therefore, we can observe that the mousse has been well-accepted by all age groups.

\subsection{Enteral formulas}

The chicken hydrolysate soup had the highest average, but it did not present a meaningful statistical difference from the beef hydrolysates although there was a difference of $5 \%$ concerning the turkey hydrolysates. The distribution of the panellists related to the hedonic scale shows that the acceptance of the soup made from beef hydrolysates was 53\%, which indicates acceptance of the product (Table 1). There were a few remarks made by the panellists from which we can point out "consistence similar to soup", "liver taste".

Concerning the soup made of chicken hydrolysates, one can notice that $62.5 \%$ of the panellists attributed values between "like slightly" (6) and "extremely like" (9), and the highest ranking was 7 , "like moderately" (25\%), which indicated acceptance of the product. The only comment referring to the soup made of chicken hydrolysates was "it is well seasoned".

With regard to the soup made of turkey hydrolysates, $47.5 \%$ of the panellists attributed scales from "like slightly" (6) to "extremely like" (9), and the highest ranking was 7 "like moderately" (22.5\%). Taking into account "neither like/ nor dislike", the rate of $57.5 \%$ was obtained, which indicates a non-rejection of the product.

Remarks concerning the turkey hydrolysate soup were: "very sticky", "dense", "strong taste", "clear flavour", features that might have contributed for the non-acceptance of the product. There were no comments as to a possible bitter taste in any of the evaluated preparations, feature that was otherwise expected due to the bitter peptides that form during the process of hydrolysis (CLEMENTE, 2000).
The selected preparations were meant to have different consistency (liquid, creamy), taste (sweet, salty, sour, and bitter), and the fact that they can be used by different age groups.

In all preparations, regardless of age, the turkey hydrolysate showed higher values of acceptance, with no statistically significant difference $(\mathrm{p}<0.05)$ from the potato balls, soup, and mousse. There was, however, difference for vitamins with the beef hydrolysate, which suggests, in this case, the use of the chicken or turkey hydrolysates.

\section{Conclusion}

The results show satisfactory acceptance, regardless of the kind of hydrolysate, the turkey hydrolysate showed the lower rejection, except for the enteral diet. The hydrolysates can be used in a wide range of preparations, including special diets, but previous knowledge of its features, both sensory and physicochemical is needed in order to maintain the taste, texture, and appearance of the final product compared to the original recipe.

\section{Acknowledgments}

The authors are grateful to FAPESP (The State of São Paulo Research Foundation) for supporting part of this research.

\section{References}

BOTT, L. et al. Contamination of gastrostomy feeding systems in children in a home-based enteral nutrition program. Journal of Pediatric Gastroenterology Nutrition, v. 33, n. 3, p. 266-270, 2001.

CHIANG, W. D.; SHIH, C. J.; CHU, Y. H. Functional properties of soy hydrolysate produced from a continuous membrane reactor system. Food Chemistry, v. 65, n. 2, p. 189-194, 1999.

CLEMENTE, A. Enzymatic protein hydrolysates in human nutrition. Trends Food Science and Technology, v. 11, n. 7, p. 254-262, 2000.

FROKJAER, S. Use of hydrolysate for protein supplementation. Food Technology, v. 48, n. 10, p. 86-88, 1994.

MEILGAARD. M.; CIVILLE, G. V.; CARR, T. B. Sensory evaluation techniques. Boca Raton: CRC Press, 1999.

NEVES, R. A. M.; MIRA, N. V. M. de; MARQUEZ, U. M. L. Caracterização de hidrolisados enzimáticos de pescado. Ciência e Tecnologia de Alimentos, v. 24, n. 1, p. 101-108, 2004.

PINTO e SILVA, M. E. M.; MAZZILLI, R. N.; BARBIERI, D. Hidrolisado protéico como recurso dietético. Jornal de Pediatria, v. 74, n. 3, p. 217-221, 1998.

PINTO e SILVA, M. E. M.; MAZZILLI, R. N.; CUSIN, F. Composition of hydrolysates from meat. Journal of Food Composition and Analysis, v. 12, n. 3, p. 219-225, 1999.

STABILE, M. N. O. et al. Carne pré-digerida a partir de suco de abacaxi. Alimentos e Tecnologia, v. 32, n. 1, p. 99-104, 1990.

ZARRABIAN, S. et al. Effects of alimentary intact proteins and their oligopeptide hydrolysate on growth, nitrogen retention, and small bowel adaptation in inflammatory turpentine rat. Nutrition, v. 15, n. 6, p. 474-480, 1999. 